JURNAL NOMOSLECA

Volume 4 Nomor 1, April 2018

\title{
GAYA KOMUNIKASI DALAM BINGKAI KEPEMIMPINAN BAGI FIGUR PEREMPUAN
}

Studi Kualitatif tentang Gaya Komunikasi dalam Bingkai Kepemimpinan bagi Perempuan di Lembaga Kajian Bahasa

\section{Ditha Prasanti, Sri Seti Indriani}

Fakultas Ilmu Komunikasi Universitas Padjadjaran

dithaprasanti@gmail.com

\begin{abstract}
Good leadership requires competence in communicating with members, how to communicate the leadership of an organization or institution to achieve its goals. In this modern society, more and more women become leaders in their organization which in some parts of society in Indonesia, It is still rare to find women responsible. This study aims to find out more about responsible women in an institution / organization that focuses on how they communicate with their members to achieve goals, so that the title that emerges in this research is "Communication Style in the Frame of Leadership for Women". The focus of this research is to know the style of leadership communication on the female figure. The research used qualitative approach with case study method. Data collection techniques used were in-depth interviews, documentation studies and observation. The fourth informants were chosen by purposive sampling technique. The results showed that leadership style of communication in this female figure include informative style; directing; confirm; participate; granting delegations; remind; and evaluation.
\end{abstract}

Keywords: Communication Style, Leadership, Women, Institute of Language Studies

\begin{abstract}
Abstrak
Kepemimpinan yang baik membutuhkan kompetensi dalam berkomunikasi dengan anggotanya, cara dalam mengkomunikasikan kepemimpinan sebuah organisasi atau institusi mencapai tujuannya. Dalam masyarakat modern ini, semakin banyak perempuan menjadi pemimpin dalam organisasinya yang di beberapa bagian masyarakat di Indonesia, Masih jarang ditemukan perempuan yang bertanggung jawab. Penelitian ini bertujuan untuk mengetahui lebih banyak tentang perempuan yang bertanggung jawab di sebuah institusi / organisasi yang berfokus pada bagaimana mereka berkomunikasi dengan anggotanya untuk mencapai tujuan, sehingga judul yang muncul dalam penelitian ini adalah "Gaya Komunikasi dalam Bingkai Kepemimpinan bagi Perempuan di Lembaga Kajian Bahasa". Fokus penelitian ini adalah untuk mengetahui gaya komunikasi kepemimpinan pada sosok perempuan di lembaga kajian bahasa yang berada di Bandung. Penelitian menggunakan pendekatan kualitatif dengan metode studi kasus. Teknik pengumpulan data yang digunakan adalah wawancara mendalam, studi dokumentasi dan observasi. Adapun 4 informan dipilih dengan teknik purposive sampling. Hasil penelitian menunjukkan bahwa gaya komunikasi kepemimpinan pada sosok perempuan ini meliputi gaya menginformasikan; mengarahkan; mengkonfirmasi; berpartisipasi; pemberian delegasi; mengingatkan; dan evaluasi.
\end{abstract}

Kata kunci: Gaya Komunikasi, Kepemimpinan, Perempuan, Lembaga Kajian Bahasa 


\section{PENDAHULUAN}

Kepemimpinan merupakan aspek yang berada dalam satu kesatuan dengan organisasi. Kita sering mendengar istilah jiwa kepemimpinan, padahal tidak terlihat wujudnya secara fisik. Tetapi kepemimpinan ini sudah bersatu dalam diri seseorang. Tidak semua orang memiliki kepemimpinan yang baik, apalagi jika kita membedakannya dari segi gender. Baik laki-laki maupun perempuan, tentu tidak menjadi penghalang jiwa kepemimpinan itu dimiliki oleh seorang individu. Pada era ini, penulis mengamati mulai berkembangnya era kepemimpinan yang didominasi oleh perempuan. Inilah yang menjadi fokus penelitian penulis dengan mengangkat sebuah institusi kajian bahasa di Bandung.

Gaya kepemimpinan diartikan sebagai perilaku atau cara yang dipilih dandipergunakan pemimpin dalam mempengaruhi pikiran, perasaan, sikap, dan perilaku organisasinya. Gaya kepemimpinan juga diartikan sebagai cara seorang pemimpin mempengaruhi perilaku bawahan, agar mau bekerjasama dan bekerja secara produktif untuk mencapai tujuan organisasi (Mathis: 2003).

Penelitian yang telah dilakukan Fitriani (2015) menceritakan tentang gaya kepemimpinan seorang perempuan. Dalam penelitiannya, dijelaskan pula bahwa dalam sebuah organisasi atau institusi, dominasi pria sebagai pemimpin memang masih begitu kuat. Padahal kenyataannya, wanita pun mempunyai potensi yang tidak kalah dengan pria dalam hal memimpin. Kepemimpinan, tidak mungkin bisa terlepas dari individu yang berperan sebagai pemimpin itusendiri. Banyak yang menghubungkan antara kemampuan individu dalam memimpin dengan aspekbiologis yang melekat pada diri sang pemimpin yaitu berdasarkan pada perbedaan jenis kelamin laki-laki dan perempuan. Hal tersebut kemudian mengakibatkan timbulnya istilah ketimpangan gender (jenis kelamin laki- laki dan perempuan) yang kemudian menempatkan perempuan pada kondisi yang tidak menguntungkan, walaupun perempuan adalah sumber daya manusia yang bahkan di seluruh dunia jumlahnya jauh lebih besar daripada laki-laki.

Pada perkembangan sekarang sudah banyak bermunculan perempuansebagai pemimpin dalam berbagai bidang, sehingga perempuan mempunyaitugas tambahan yaitu selain sebagai ibu rumah tangga juga sebagai pemimpin.Reformasi di Indonesia telah memberikan harapan yang besar bagikaum perempuan yang selama ini terpasung dalam segala hal. Kebangkitankaum perempuan dalam era globalisasi pola kehidupan telah membawa perubahan dalam perkembangan pembangunan. Pada masa saat ini, pada diriperempuan melekat multi peran, tidak lagi terpaku pada peranan menjadi istriatau ibu semata-mata, tetapi telah terorientasi pada pemanfaatan kualitaseksistensinya selaku manusia (Fitriani: 2015).

Menurut Nurkolis (2003), kepemimpinan adalah proses memengaruhi atau memberi contoh oleh pemimpin kepadapengikutnya dalam upaya mencapai tujuan organisasi selanjutnya definsi lain, yang cukup sederhana, diajukan oleh Mullins, bahwa kepemimpinan adalah $a$ relationship through which one person influencesthe behaviour or actions of other people. Definisi Mullins menekankan pada konsep "hubungan" yang dimana melalui seseorang mempengaruhi perilaku atau tindakan orang lain. Kepemimpinan dalam tersebut dapat berlaku baik di organisasi formal, informal, ataupun non formal.

Dalam penelitian sebelumnya yang telah dilakukan oleh penulis, Prasanti (2018) juga menemukan adanya pola komunikasi figur perempuan dalam kepemimpinan pendidikan islam. Hasil penelitian ini menunjukkan posisi perempuan dalam kepemimpinan sebuah lembaga pendidikan islam, yaitu Pendidikan Anak Usia Dini (PAUD). Posisi perempuan tersebut ditunjukkan 
melalui pola komunikasi figur perempuan dalam kepemimpinan pendidikan Islam di lembaga tersebut memiliki ciri khas tertentu yang berbeda dengan lembaga lainnya. Pola komunikasi verbal yang dilakukan oleh kepala sekolah yaitu seorang perempuan melalui sekretarisnya laki-laki, menggunakan bahasa verbal yang menerapkan nilai-nilai Islam. Dalam lembaga PAUD ini, segala keputusan dipegang oleh sekretarisnya karena ajaran Islam, laki-laki yang berwenang memberikan keputusan dalam segala kegiatan di PAUD tersebut. Pola komunikasi nonverbal berupa pesan non verbal Islami diterapkan oleh kepala sekolah melalui konsep senyum, salam, sapa, dan sopan santun menjadi budaya dalam lembaga pendidikan Islam tersebut (Prasanti: 2018).

Berbeda halnya dengan beberapa penelitian terdahulu di atas, penulis mengambil fokus penelitian yang lain disini yaitu mengenai gaya komunikasi dalam bingkai kepemimpinan bagi perempuan. Dalam penelitian sebelumnya, penulis mengangkat tentang kepemimpinan perempuan dalam lembaga pendidikan PAUD islam di mana segala keputusan didiskusikan dengan wakil kepala sekolahnya, laki-laki, bahkan seringkali juga menyerahkan keputusan kepada wakil kepala sekolahnya (Prasanti: 2018). Sedangkan dalam penelitian ini, penulis ingin mengetahui gaya komunikasi dalam bingkai kepemimpinan yang digunakan figur perempuan.

Berdasarkan latar belakang tersebut, penulis tertarik untuk melakukan penelitian ini. Kepemimpinan yang berhasil membutuhkan komunikasi kepada bawahannya dengan baik. Dalam hal ini, gaya komunikasi kepemimpinan tentu digunakan untuk mencapai tujuan yang diinginkan dalam sebuah organisasi/ lembaga. Bukanlah hal yang aneh lagi, untuk era modern saat ini, kita bisa melihat adanya lembaga atau organisasi yang dipimpin oleh laki-laki dan perempuan. Kita pun dapat melihat adanya gaya komunikasi kepemimpinan dalam figur perempuan tersebut pada lembaga pendidikan. Fenomena ini merupakan masalah yang menarik untuk diteliti. Peneliti Berdasarkan fenomena tersebut, peneliti tertarik untuk mengangkat penelitian tentang "Gaya Komunikasi dalam Bingkai Kepemimpinan bagi Perempuan”.

\section{Gaya Komunikasi dalam Organisasi}

Mempelajari organisasi adalah mempelajari perilaku pengorganisasian dan inti perilaku tersebut adalah komunikasi setelah mengetahui hakikat organisasi dan komunikasi, maka kita dapat melihat arah dan pendekatan yang ada pada komunikasi organisasi. "Komunikasi organisasi lebih dari sekedar apa yang dilakukan orangorang, komunikasi organisasi adalah suatu disiplin ilmu yang dapat mengambil sejumlah arah yang sah dan bermanfaat" (Pace dan Faules, 2002:25).

Analisis komunikasi organisasi menyangkut penekanan atas banyak transaksi yang terjadi secara stimuli. Sistem tersebut menyangkut pertunjukan dan penafsiran pesan diantara puluhan bahkan ratusan individu pada saat yang sama, yang memiliki jenis-jenis hubungan berlainan yang menghubungkan mereka dimana pikiran, keputusan dan perilakunya diatur oleh kebijakan-kebijakan, regulasi, dan aturan-aturan, yang mempunyai gaya berlainan dalam berkomunikasi. Mengelola dan memimpin yang dimotivasi oleh kemungkinankemungkinan yang berada pada tahan perkembangan berlainan dalam berbagai kelompok; yang memiliki iklim komunikasi berbeda; yang mempunyai tingkat kepuasan berbeda dan tingkat kecukupan informasi yang berbeda pula; yang lebih menyukai dan menggunkan jenis, bentuk, dan metode komunikasi yang berbeda dalam jaringan yang berbeda; yang mempunyai tingkat ketelitian pesan berlainan; dan yang membutuhkan penggunaan tingkat materi dan energi yang berbeda 37 untuk berkomunikasi efektif. "Interaksi diantara semua faktor tersebut, 
dan mungkin lebih banyak lagi disebut sistem komunikasi organisasi”. (Pace dan Faules, 2002:33)

Menurut Mulyasa (2002:165) gaya komunikasi didefinisikan sebagai seperangkat perilaku antar pribadi yang terspesialisasi yang di gunakan dalam suatu situasi tertentu (a spesialized set of interpersonal behaviors that are used in a given situation). Setiap gaya komunikasi terdiri dari sekumpulan perilaku komunikasi yang dipakai untuk mendapatkan respons atau tanggapan tertentu dalam situasi yang tertentu pula. Kesesuaian dari satu gaya komunikasi yang digunakan, tergantung pada maksud dari pengiriman (sender) dan harapan dari penerima (receiver).

Menurut Mulyasa (2002:165- 166), dalam melakukan komunikasi, pemimpin memiliki ciri khas masing-masing dalam memimpin organisasinya. Ada enam gaya komunikasi yang dilakukan oleh seorang pimpinan, yaitu:

a. The controlling style

$b$. The equalitarian style

c. The structuring style

d. The dynamic style

$e$. The relinguishing style

$f$. The wibdrawal style

\section{METODE PENELITIAN}

Pendekatan penelitian yang digunakan dalam penelitian ini adalah pendekatan kualitatif dengan metode deskriptif. Metode deskriptif adalah suatu metode dalam meneliti setatus sekelompok manusia, suatu obyek, suatu set kondisi, suatu sistem pemikiran, ataupun suatu kelas peristiwa pada masa sekarang. Tujuan dari penelitian deskriptif ini adalah untuk membuat deskipsi, gambaran atau lukisan secara sistematis, faktual dan akurat mengenai fakta-fakta, sifat-sifat serta hubungan antar fenomena yang diselidiki. "Metodologi adalah proses, prinsip, dan prosedur yang kita gunakan untuk mendekati problem dan mencari jawaban" (Mulyana, 2008: 145).
Menurut Sugiyono (2007: 1), metode penelitian kualitatif merupakan suatu penelitian yang digunakan untuk meneliti pada objek yang alamiah dimana peneliti adalah sebagai instrumen kunci, teknik pengumpulan data dilakukan secara gabungan, analisis data bersifat induktif, dan hasil penelitian kualitatif lebih menekankan makna daripada generalisasi.

Penelitian kualitatif bertujuan mempertahankan bentuk dan isi perilaku manusia dan menganalisis kualitaskualitasnya, alih-alih mengubahnya menjadi entitas-entitas kuantitatif (Mulyana, 2003: 150). Mengenai tipe deskriptif, Jalaludin Rakhmat dalam buku Metode Penelitian Komunikasi menjelaskan bahwa "Penelitian deskriptif hanyalah memaparkan situasi atau peristiwa. Penelitian ini tidak mencari atau menjelaskan hubungan, tidak menguji hipotesis atau membuat prediksi" (Rakhmat, 2002: 24).

\section{Teknik Pengumpulan Data}

Teknik pengumpulan data dalam penelitian kualitatif adalah dengan melakukan observasi, wawancara mendalam, dan studi dokumentasi.

1) Observasi

2) Wawancara

3) Studi Dokumentasi

\section{Informan Penelitian}

Teknik pengambilan informan dilakukan dengan metode sampling purposive, yaitu pemilihan informan sesuai dengan kebutuhan penelitian. Adapun informan dalam penelitian ini adalah:

1. ES, pendiri tunggal sekaligus penasehat lembaga kajian bahasa

2. IK, pemimpin lembaga kajian bahasa

3. SR, pengelola lembaga kajian bahasa

4. PT, pengelola lembaga kajian bahasa 
HASIL DAN PEMBAHASAN

\section{Gaya Komunikasi dalam Lembaga Kajian Bahasa}

Jika ditinjau secara konseptual, gaya komunikasi (communication style) didefinisikan sebagai seperangkat perilaku antar pribadi yang terspesialisasi yang digunakan dalam suatu situasi tertentu ( $a$ specialized set of intexpersonal behaviors that are used in a given situation). Setiap gaya komunikasi terdiri dari sekumpulan perilaku komunikasi yang dipakai untuk mendapatkan respon atau tanggapan tertentu dalam situasi yang tertentu pula. Kesesuaian dari satu gaya komunikasi yang digunakan, bergantung pada maksud dari pengirim (sender) dan harapan dari penerima (receiver) (Efendi: 2001).

Adapun gaya komunikasi yang terdapat dalam hasil penelitian ini meliputi: gaya memerintahkan; gaya mengingatkan; gaya mengkonfirmasi; gaya berpartisipasi; gaya pemberian delegasi; gaya mengingatkan; dan gaya evaluasi.

Wawancara dan pengamatan telah dilakukan pada 4 orang perempuan yang sama-sama bekerja di sebuah sekolah bahasa Inggris. Setiap informan memiliki tanggung jawab mereka pada divisi mereka masing-masing, yangmana memerlukan kemampuan dalam memimpin. ES yang merupakan pendiri tunggal dari lembaga pendidikan bahasa Inggris tersebut memulai kiprahnya pada tahun 1992. Ia memulai dengan 5 murid dengan menggunakan garasi rumah sebagai kelas, dan kini pada tahun 2017, setelah 25 tahun ia sudah memiliki kurang lebih 800 murid aktif dengan 20 staff yang menjadi tanggung jawabnya.

IK yang merupakan putri tunggal dari ES karena pertambahan siswa dari tahun ke tahun, kemudian dijadikan kepala sekolah sejak tahun 2005, pengangkatan tersebut pada awalnya hanya bersifat 'status' karena salah satu syarat adanya sebuah lembaga pendidikan diperlukan adanya seorang kepala sekolah. Namun, pada akhirnya IK menjalankan tugasnya sebagaimana seorang kepala sekolah pada umumnya, yang kurang lebih mengkoordinir kurrikulum pelajaran dan para guru dan staff yang bekerja disana. IK tidak sendiri dalam memanage sekolah tersebut, ia diperbantukan oleh dua perempuan lainnya yakni PT yang berurusan dengan kurrikulum dan pengawas akan jalannya sebuah sekolah, dan SR yang berurusan dengan administrasi, dan keuangan sekolah.

Keempat informan tersebut merupakan perempuan-perempuan yang masing-masing memiliki peran penting dalam menjalankan lembaga bahasa Inggris ini. Adapun struktur organisasi yang terdapat dalam lembaga/sekolah bahasa inggris tersebut, struktur organisasi tersebut dibuat agar masing-masing memahami tanggung jawabnya serta untuk memperlancar jalur komunikasi yang terjadi dalam organisasi tersebut, hal ini bertujuan agar tidak terjadi tumpang tindih dan salah pengertian diantaranya.

Struktur organisasi yang ada juga menunjukkan bahwa lembaga atau sekolah bahasa Inggris tersebut kurang lebih dipimpin oleh perempuan, dan setelah dilakukan wawancara dan pengamatan terhadap keempat informan diatas (ES, IK, SR dan PT) ada kurang lebih tujuh gaya komunikasi kepemimpinan dalam figur perempuan di lembaga pendidikan, yaitu:

1. Menginformasikan/Memerintahkan Gaya komunikasi yang pertama dilakukan oleh para perempuan ini diawali dengan cara menginformasikan sesuatu yang harus dilakukan oleh anggota yang berada dibawah tanggung jawabnya. IK memaparkan bahwa gaya menginformasikan ataupun memerintahkan suatu dilakukan dengan sopan dan santun dan berhati-hati, sehingga tidak terkesan 'bossy'. Pengucapan seperti 'please' dan 'thank you' tidak lupa digunakan setap kali memerintahkan sesuatu. 
IK menceritakan bahwa menjadi seorang pemimpi ingin lebih ditegaskan daripada menjadi seorang 'boss', ia mengakui hal tersebut pada awalnya sulit dilakukan, karena pada awalnya ia mulai menjadi seorang kepala sekolah diusia yang muda, sehingga pada awal kepemimpinannya, banyak teguran bahwa cara penyampaian 'perintah' terkesan 'bossy', namun seiring sejalan, ia pun dapat mempelajari gaya 'memerintah' dengan sopan dan santun. PT pun pada awalnya mengakui bahwa terkadang ia merasa 'tidak enak', menyuruh/ memerintahkan sesuatu, namun, pada akhirnya IK membantunya untuk memberi penjelasan kepada anggotanya bahwa ia memiliki tanggung jawab, dan hal tersebut dilakukan adalah untuk kebaikan lembaga/sekolah tersebut.

2. Mengarahkan

Pola komunikasi yang terjadi didalam lembaga/sekolah ini terjadi secara dua arah, apabila sudah menginformasikan suatu perintah, pemimpin figure perempuan ini mengarahkan cara bagaimana mereka dapat melakukan perintah tersebut dengan baik dan benar sesuai dengan tujuan yang ingin dicapai. Saling tukar pemikiran tentang bagaimana menyelesaikan suatu tugas antara pemimpin dan anggotanya, sehingga mereka saling memahami satu dengan lainnya akan penugasan tersebut. Ucapan seperti 'ok' seringkali digunakan untuk menyatakan bahwa anggota memahami apa yang harus dilakukan.

3. Mengkonfirmasi

Eliciting merupakan kegiatan mengkonfirmasi kembali apakah apa yang ditugaskan/diperintahkan sesuai dengan apa yang telah disampaikan kepadanya. Kegiata eliciting ini berperan penting dalam tiap penugasan, hal ini dilakukan untuk meminimalisasikan kesalahphahaman dalam menjalankan sebuah tugas. Contoh ketika SR memberikan pengarahan kepada beberapa anggota 'Catroops';

SR: 'so, what you need to do is to come at 10 sharp on Sunday morning, make sure the new students and parents enroll again by signing their names, ask them to wait, after that at 10.30, they all must form a line, students go to room $E$ and parents go to room $K$.' Catroops: ok

SR: so what time do you need to come?

Catroops: 10 sharp

SR: what must the new students and parents do?

Catroops: they must enroll again by signing names at the front desk

SR: what time do they form a line

Catroops: 10.30

SR: which room do parents go to?

Catroops: room $K$

SR: and new students?

Catroops: room E

4. Berpartisipasi

Tidak jarang para pemimpin figure perempuan ini ikut berpartisipasi dalam apa yang sebelumnya ia tugaskan kepada anggotanya, hal tersebut dilakukan adalah selain untuk ikut memberikan kontribusi agar penugasan dapat diselesaikan dengan tepat waktu, juga dlakukan untuk melihat apakah penugasan tersebut dilakukan sebagaimana mestinya. Sebagai salah satu contohnya adalah peraturan 'Loving Time'. Loving Time' adalah suatu budaya dimana seluruh anggota lembaga kajian bahasa pun ikut memelihara lingkungan tempat mereka belajar atau bekerja, seperti menyapu, mengepel, memelihara 
kebersihan, pengecekan dan sebagainya. Para figur perempuan ini tidak hanya memerintahkan namun juga ikut melakukan hal yang sama.

Contoh lainnya adalah ketika terdapat rapat 'Catroops', dimana sudah ada yang bertanggung jawab didalamnya, namun para pemimpin figure perempua ini turut berpartisipasi dalam rapat, meskipun bentuknya tidak mengendalikan rapat tersebut, ia berperan hanya sebagai pengingat dan pengawas dan juga memberikan saran apabila diminta oleh yang langsung memiliki tanggungjawab penuh terhadap kegiatan tersebut. 'Catroops' itu sendiri merupakan perkumpulan murid-murid pilihan yang teladan dan menjadi asisten guru, serta aktif dalam setiap kegiatan sekolah.

5. Pemberian Delegasi

Pemimpin figure perempuan ini mengakui bahwa pada awalnya mengerjakan segala sesuatu sendiri tampak lebih mudah, karena segala sesuatu dapat dicapai sesuai dengan target capaian yang diinginkan, terkadang rasa kurang percaya terhadap penugasan kepada orang lain muncul dengan sendirinya, baik perasaan curiga bahwa anggota tidak mampu melakukan dengan baik, ataupun anggota tidak sepeduli seorang pemimpin dengan apa yang harus dilakukan untuk kemajuan lembaga/sekolah tersebut. Namun, mereka pun mengakui bahwa tidak mungkin bisa mereka melakukan semua pekerjaan sendiri, maka daripada itu mereka memberikan delegasi kepada orang lain. Mereka membangun'trust' kepada orang yang diberi delegasi, dan menanamkan rasa tanggung jawab dan 'power' terhadap mereka. Para perempuan ini mengambarkan pada awalnya memiliki keraguan dalam tindakan tersebut, namun dari pengalaman, semakin tinggi rasa 'percaya' mereka tanamkan terhadap orang lain, maka semakin tinggi pula kinerja yang dilakukan orang lain tersebut. Meskipun tetap semua dalam pengawasan.

6. Mengingatkan

Mengingatkan akan tugas dan delegasi merupakan sesuatu yang dilakukan oleh para figur perempuan ini dalam memimpin. Mereka menceritakan bahwa mereka kerap mengingatkan tugastugas atau aturan atura tersebut, karena terkadang terdapat 'kelengahan' yang mana peraturan mulai 'kendor' yang mengakibatkan ketidaklancaran sistem yang ada.

7. Evaluasi

Setiap kegiatan atau penugasan yang telah selesai dilakukan selalu diakhiri dengan waktu evaluasi, hal ini untuk mengetahui kelebihan dan kekurangan, positif dan negaif suatu kegiatan. Acara evaluasi ini adalah signifikan karena dapat memperbaiki kesalahan-kesalahan yang dilakukan dan memperbaikinya, sehingga kegiatan yang akan dilakukan selanjutnya akan lebih baik dari sebelumnya.

\section{PENUTUP}

\section{Simpulan dan Saran}

Penelitian yang telah dilakukan penulis ini menghasilkan pandangan baru tentang "Gaya Komunikasi dalam Bingkai Kepemimpinan bagi Perempuan". Setelah dilakukannya penelitian, penulis dapat menyimpulkan bahwa gaya komunikasi kepemimpinan yang dimiliki oleh para perempuan yang berada disini adalah tujuh gaya komunikasi tersebut, terdiri dari; gaya memerintahkan; gaya mengingatkan; gaya mengkonfirmasi; gaya berpartisipasi; 
gaya pemberian delegasi; gaya mengingatkan; dan gaya evaluasi.

\section{DAFTAR PUSTAKA}

Effendy, Onong Uchjana.2001. Ilmu Komunikasi Teori dan Praktek. Bandung : PT. Remaja Rosdakarya

Faules, R. Wayne Pace Don F. 2010. Komunikasi Organisasi. Bandung: PT. Remaja Rosdakarya.

Fitriani, A. 2015. Gaya Kepemimpinan Perempuan. Jurnal Tapis, 11(2).

Mathis, Robert dan John Jackson. 2003. Manajemen Sumber Daya Manusia Buku 2. Jakarta: PT. Salemba 4.

Mulyana, Deddy. 2008. Metodologi Penelitian Kualitatif. Bandung : PT Remaja Rosdakarya.

Mulyasa. 2002. Pimpinan dan Kepemimpinan. Jakarta: Raja Grafindo Perkasa.

Nurkolis. 2003. Manajeman Berbasis Sekolah: Teori, Model dan Aplikasi". Jakarta: Grasindo

Prasanti, D. 2018. Pola Komunikasi Figur Perempuan dalam Kepemimpinan Pendidikan Islam. Jurnal Komunikasi Global, 6(2), 117-130.

Rakhmat, Jalaludin. 2002. Metode Penelitian Komunikasi. Bandung: PT Remaja Rosdakarya.

Sugiyono. 2007. Metode Penelitian Kuantitatif $\&$ Kualitatif RND. Bandung: Alfabeta. 